\title{
The Effect of Family Ownership on the Relationship between Busy Directors and Stock Price Crash Risk for Listed Firms on the Indonesia Stock Exchange
}

\author{
Siti Fatimah Zachro ${ }^{1 *}$, Cynthia Afriani Utama ${ }^{2}$ \\ 1,2Master of Management, Faculty of Economics and Business, Indonesia University \\ ${ }^{*}$ Corresponding Author: fatimahzachro@gmail.com
}

\begin{abstract}
This study explores the impact of busy directors on the stock price crash risk if an individual holds three or more board positions. Since Indonesia has adopted a two-tier system, directors refer to Commissioners. Most of the literature suggests that the main risk factor for stock price crashes arises from the tendency of management to withhold adverse news from investors regarding compensation contracts and career issues. This research aims to verify whether busy directors help to limit managerial opportunistic behavior. Results show that multiple positions bring no effect on the stock price crashes risk due to cross over interaction which negated the substantial effect on the risk of stock price crashes. As a country with high family ownership concentration, the results illustrate that family firms in Indonesia will strengthen the influence of Commissioners who hold multiple positions in reducing stock price crashes risk. This investigation uses a sample of companies listed in the Indonesia Stock Exchange over the period between 2014 and 2019. The generalized method of moment (GMM estimator) is used as a research method to reduce endogeneity problems.
\end{abstract}

Keywords $\quad$ : busy directors; board of commissioner; family firms; stock price crash risk

JEL Classification : G13 G32

\section{INTRODUCTION}

The risk of a stock price crash has become a crucial consideration for investment decisions and risk management. Since the 2007-2008 global financial crises, the issue of the stock price crash has attracted the regulators, practitioners and scholars to examine its various influential factors. Stock price crash risk is also defined as the conditional skewness of the distribution of stock returns. This indicates an asymmetry in the risks associated with stocks. From the research of Callen \& Fang (2013) and Kim \& Zhang (2014), companies with high agency risk tend to experience stock price crashes. Problems related to career and manager compensation can lead to asymmetry information to withhold negative information (company earnings that are far below expectations) so that stock prices do not plummet in short term (Kothari et al., 2009). Managers can do this by aggressively managing earnings in form of overestimating revenue realization. However, 
withholding, delaying, or accumulating the disclosure of bad news cannot last long and will eventually lead to a considerable fall in stock prices (Bleck \& Liu, 2007; Callen \& Fang, 2013; Kim \& Zhang, 2016). Thus, conceptually, the risk of stock crash is based on the assumption that managers tend to conduct earnings management aggressively over a certain period of time. Jin \& Myers (2006) is one of the foundations of a study on stock price crashes who states that asymmetry information occurs between managers and shareholders and managers' personal interests affects stock price crashes risk.

In the context of Indonesia, hiding or withholding unfavorable news refers to management's discretionary actions in aggressively managing earnings. PSAK as the basic framework for the preparation of financial statements provides flexibility for management to perform earning smoothing. Management is given discretion using the accrual method which can be based on judgment in recognizing revenue. The gap in earnings management as stated in PSAK No. 1 (Revised 2009) due to the existence of an Accrual Basis as a general characteristic of financial statements, where income or expenses can be recognized when it has been incurred. Other regulations, such as the Capital Market Law and the Company Law, impose administrative and criminal sanctions for presenting misleading financial reports. However, with the discretionary judgment regarding revenue recognition facilitated by PSAK, this can shelter management under the principles of the business judgment rule. Hence, the problem of earning smoothing in Indonesia becomes an ethical dilemma.

Good corporate governance serves as an effective mechanism to diminish opportunistic management behavior, to improve the quality of accounting information, and to increase firm value (Alkurdi et al., 2019). The failure of the corporate governance system has been considered to be the leading factor causing the erosion of shareholder value resulting in a crash in stock prices. The reform wave emphasized board practices such as the presence of outside or independent directors on the board and audit committee and the separation of CEO and Chairman positions. This emphasis is consistent with the idea that board of commissioner is a key element of corporate governance that increases management oversight and reduces agency problems (Utama and Utama, 2019). In a one-tier system arrangement, the board that carries out supervision of management actions is outside directors or independent directors who are not part of the company's executive team (Fich and Shivdasani, 2006). This study uses data from Indonesia, where the governance structure is based on a two-tier system. As stated in Law No. 40 of 2007 concerning Limited Liability Companies, there are three company's organs consisting of shareholders, a board of commissioners and a board of directors. Commissioners obtain delegations of power from shareholders to carry out supervision, including the responsibility to design and approve managerial compensation, to maintain accountability for financial statements, and to appoint external auditors. Since the role of directors is identical to the role played by Commissioners in Indonesia, this study will analyze Commissioners. Referring to the reputational hypothesis, reputation incentives will make the Commissioners become effective supervisors by encouraging managers not to carry out aggressive earnings management. This will assist the company to minimize the risk of a stock price crash.

Indonesia has the characteristics of concentrated ownership, where the largest share ownership is dominated by family members. Family ownership is used as a moderating variable to observe whether the interaction between family ownership and commissioner with multiple position is able to reduce stock price crashes risk. The presence of family 
ownership can be the supervisor who controls the company's decisions for the best interests of all shareholders. Ali et al., (2007) and Srinidhi \& Liao (2020) show that family firms provide better quality income reports and tend not to perform aggressive earnings management. Family firms are more open in disclosure than non-family ones. Hence, the warning regarding earning smoothing is expected to have the potential to reduce stock price crashes. The results of this study indicate that the interaction of family ownership with commissioners with multiple positions in Indonesia shows an alignment effect with respect to the risk of stock price crashes. As explained by Jensen and Meckling (1976), large block holders tend to reduce agency problem conflicts because they have the power and incentives to monitor managers. We hope that this study can contribute to a broader discussion whether family ownership is a good or bad organizational structure by taking it as moderating variable.

Stock price crash risk is based on the bad news hoarding theory developed by Jin and Myers (2006), a manager as information controller whose task is to disclose specific information about the company has an incentive to hide adverse information to withstand risks that can impact the company's reputation. Managers who withhold the flow of negative information to the market will result in an asymmetric distribution of shares (Hutton et al., 2009; Kotahari et., Al 2009). Needless to say, the adverse news is certainly not going to last long. When it finally reached the threshold, the manager could no longer hold it back. Disclosure of information is unavoidable and will cause a crash in the stock price manifested by the distribution of stock returns which tends to form a peak to the right. Firm-specific information that is integrated into the stock price is influenced by two factors: the investors' own incentives to collect company information and the information on the company's environment.

The first measure of crash risk was first proposed by Chen et al. (2001) which is based on skewness. NCSKEW scores for each company ${ }_{j}$ in year $t$, NCSKEW is calculated as:

$$
\operatorname{NCSKE}_{j, t}=-\frac{n-(n-1)^{\frac{3}{2}} \sum W_{j, t}^{3}}{(n-1)(n-2)\left(\sum W_{j, t}^{2}\right)^{3 / 2}}
$$

where $\mathrm{n}$ indicates the number of trading weeks on the share of company ${ }_{j}$ in year $\mathrm{t}_{\mathrm{t}}$ Higher NCSKEW values indicate higher crash risk. Negative (positive) values on skewness indicate data that is skewed to the left (right). The minus sign indicates that an incline in NCSKEW makes the company 'cash prone' - it has a more right-sloping distribution. In other words, when the NCSKEW value gets lower, the return distribution has a positive slope (positively skewed) since the frequency of the return distribution is more on the left. This indicates low crash risk and vice versa. Before obtaining the value of $W_{j, t}$, we have to regress the firm weekly return of a particular company against the market return or by using the market model in order to obtain a firm specific weekly return $\left(W_{j, t}\right)$. The market model regression is performed to eliminate market effects on returns. The following is the model index regression formula used to obtain the value of $\varepsilon i, t$ (Hutton et al. (2009)):

$$
r_{j, \mathrm{t}}=\alpha_{\mathrm{i}, \mathrm{t}}+\beta_{1, \mathrm{i}} r_{\mathrm{m}, \mathrm{t}-2}+\beta_{2, \mathrm{j}} r_{\mathrm{m}, \mathrm{t}-1}+\beta_{3, \mathrm{i}} r_{\mathrm{m}, \mathrm{t}}+\beta_{4, \mathrm{i}} r_{\mathrm{m}, \mathrm{t}+1}+\beta_{5, \mathrm{i}} r_{\mathrm{m}, \mathrm{t}+2}+\varepsilon_{\mathrm{i}, \mathrm{t}}
$$

where $r_{j, t}$ is the return on stock ${ }_{\mathrm{j}}$ in weeks ${ }_{\mathrm{t}}$ and $r_{\mathrm{m}, \mathrm{t}}$ is the weekly market return. This 
equation will use the market and firm returns two weeks before and two weeks after to take into account microstructure noise or stocks with low transaction frequency. $\varepsilon_{\mathrm{i}, \mathrm{t}}$ value is the residual value of the regression which is the firm specific return used to obtain the $W_{j, t}$ value by using the formula of $W_{j, t}=\ln \left(1+\varepsilon_{\mathrm{i}, t}\right)$.

The second measure of stock price crash risk is DUVOL (down to up volatility) which is used in the study (Andreou et al., 2016 J. Chen et al., 2001; Kim et al., 2011b) by categorizing the level of weekly stock returns. as a down week if the firm-specific weekly return is lower than the average stock return in year $t$ and categorizes the weekly stock return as an up week if the firm-specific weekly return is higher than the average stock yield in the year t. $n_{u}$ is the number of up weeks, and $n_{d}$ is the number of down weeks. Afterward, calculate DUVOL using the logarithm of the down week standard deviation divided by the logarithm of the up week standard deviation.

$$
\operatorname{DUVOL}_{t}=\log \frac{\left[\left[\left(n_{u}-1\right) \sum_{\text {down }} W_{j, t}^{2}\right]\right.}{\left.\left[\left(n_{d}-1\right)\right] \sum_{u p} W_{j, t}^{2}\right]}
$$

\section{HYPOTHESES DEVELOPMENT}

Research by Fama \& Jensen, 1983 is a pioneering journal which states that the market for outside directors offers an important source of incentives for them to develop their reputation as credible supervisors. By sitting on multiple boards, directors gain more experience and connections. Therefore, they provide better suggestions and input (Field et al., 2013). Experience and reputational incentives can make Commissioner as effective supervisor. Thus, to improve reputation in the labor market, commissioner with multiple positions should encourage managers not to carry out earnings management aggressively in order to reduce future stock price crashes. We expect that the more individual (Commissioner) hold multiple positions, stock price crash risk can be suppressed.

$\mathbf{H}_{1}$ : Busy directors are influential in reducing stock price crash risk.

Family firms invest for the long term, making them less interested in short term returns, especially if it endangers long term returns. In his role as manager, the family insider has little reason to hold back unfavorable news just to maintain or temporarily increase the share price. The reason behind this, it will result in a crash that will erode temporary profits, create volatility, and tarnish the reputation of the family (Srinidhi \& Liao, 2020). Quick exposure of negative news can reduce stock price crashes. Anderson and Reeb (2003) found that family firms perform better and have higher intrinsic value than nonfamily firms because of lower Type 1 agency costs. Chen et al. (2008) show that family firms provide more warnings regarding the transparency of income reports than non-family firms. On that basis, the interaction between family ownership and busy directors is expected to reduce the risk of stock price crashes.

$\mathbf{H}_{2}$ : Family ownership strengthens the influence of busy directors in reducing stock price crash risk. 


\section{RESEARCH METHOD}

This study uses the Generalized Method of Moment (GMM) method which is considered more appropriate in observing the effect of the dynamic relationship between the dependent variable and its lagged value. The GMM estimator developed by (Arellano \& Bond, 1991; Arellano \& Bover, 1995; Blundell \& Bond, 2000) improves the estimation of ordinary least squares (OLS) and the estimation of fixed effects. Wintoki et al., (2012) describe several advantages of using GMM estimation if there is a lag value, such as (1) it is possible to include firm fixed effects to explain unobserved firm heterogeneity; (2) GMM considers the impact of the previous stock price crash on the current state of corporate governance in the company; (3) GMM explains simultaneity by using a combination of variables from company history as a valid instrument (Wintoki et al., 2012). In addition, the study of stock price crash risk is a research that uses the dependent lagged value of the regressors. This can lead to endogeneity, since there is an influence on the dynamic relationship between the dependent variable and its lagged value. Ignoring sources of endogeneity can bias the consequences of research. This is due to concerns over endogeneity issues as previously described, as well as the relationship between busy directors and the risk of crash in dynamically endogenous stock prices. Thus, the problem is solved by using the dynamic GMM estimator panel in the following form:

Model 1 (The Famown variable is used as a continuous variable)

CRASH RISK $=\alpha+\beta_{1} \%$ BusyDir $+\beta_{2}$ Bsize $+\beta_{4}$ Famown $+\sum$ control $+\varepsilon_{i}$

Model 2 (The Famown variable is used as a moderating variable)

CRASH RISK $=\alpha+\beta_{1} \%$ BusyDir $+\beta_{2}$ Bsize $+\beta_{4}$ Famown $+\beta_{4} B D *$ Famown

$$
+\sum \text { control }+\varepsilon_{i}
$$

Note:

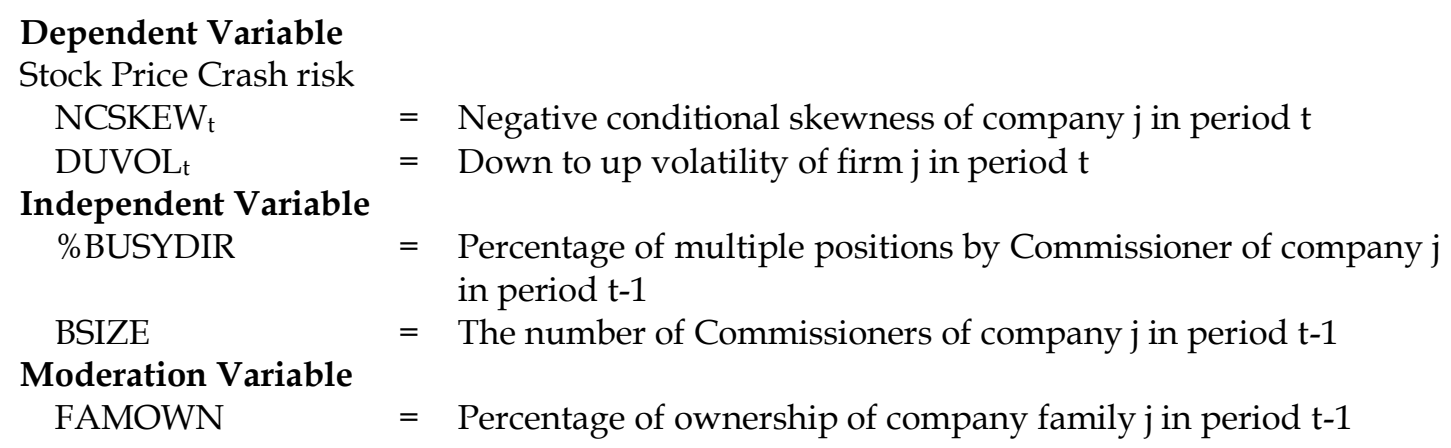

\section{Control Variable}

NCSKEW $_{j, t-1}$

DUVOL $_{j, t-1}$

DTURN $N_{j, t-1}$

$R E T_{j, t-1}$

$\operatorname{SIGM} A_{j, t-1}$
$=$ Negative conditional skewness of firm $\mathrm{j}$ in period $\mathrm{t}-1$

$=$ Down to up volatility on company $\mathrm{j}$ in period $\mathrm{t}-1$

$=$ the average of monthly stock turnover of company $\mathrm{j}$ during year $\mathrm{t}-1$

$=$ firm specific cumulative returns on shares during the year $\mathrm{t}-1$

$=$ Standard deviation of the weekly return of company $\mathrm{j}$ in period $\mathrm{t}-1$ 


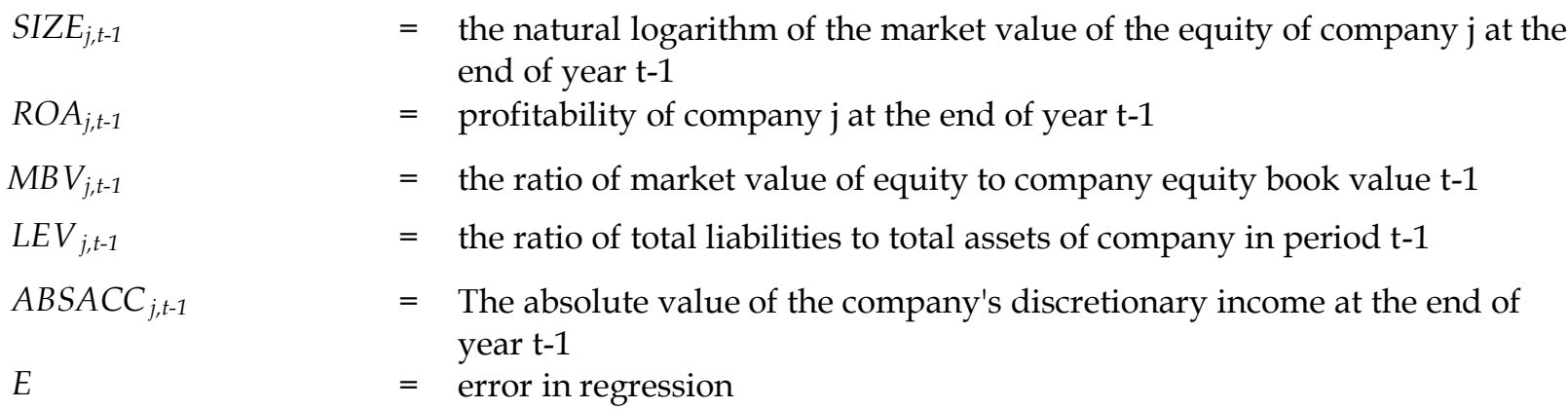

In regard with absolute accrual (ABSACC), Hutton et al. (2009) show that there is a positive relationship between earnings management and the risk of stock price crashes using discretionary accruals as a proxy for earnings management. Earning management carried out by management is proven to block the flow of firm specific information to the market and this will result in a stock price crash risk. To get discretionary accruals, firstly, we have to find the value of total accrual using the calculation of the Modified Jones Model (Dechow et al., 1995). Because discretionary accruals and non-discretionary accruals are the components of total accruals. The following is the formula for finding the value of total accrual of company $\mathrm{j}$ in year $\mathrm{t}$ :

$$
T A_{t}=\frac{\Delta C A_{i, t}-\Delta C L_{i, t}-\Delta C A S H_{i, t}+\Delta S T D_{I i, t}+-D E P_{i, t}}{A_{i, t-1}}
$$

Information:

$\begin{aligned} \Delta C A_{i, t} & =\text { change in current assets } \\ \Delta C L_{i, t} & =\text { change in current liabilities } \\ \Delta C A S H_{i, t} & =\text { change in cash } \\ \triangle S T D_{I i, t} & =\text { change in short-term debt } \\ D E P_{i, t} & =\text { depreciation expense } \\ A_{i, t-1} & =\text { total assets in the previous period }\end{aligned}$

The next step in to find the value of non-discretionary accrual formulated as follows:

Information:

$$
\text { Non }- \text { DiscAcc }=\alpha_{1}\left(\frac{1}{A_{j, t-1}}\right)+\alpha_{2}\left(\frac{\Delta R E V_{j, t}-\Delta R E C_{j, t}}{A_{j, t-1}}\right)+\alpha_{3}\left(\frac{P P E_{j, t}}{A_{j, t-1}}\right)
$$

$A_{j, t-1}=$ Total assets in the previous period

$\triangle R E V_{j, t}=$ Change in income between

$\triangle R E C_{j, t} \quad=\quad$ Change in accounts receivable

$P P E_{j, t} \quad=\quad$ Fixed assets consisting of land, buildings and buildings

To obtain the value of $\alpha_{1}, \alpha_{2}$ dan $\alpha_{3}$, OLS regression is performed through the following equation:

$$
\frac{T A}{\text { Assets }_{t-1}}=\alpha_{1} \frac{1}{\text { Asset }_{t-1}}+\alpha_{2} \frac{\triangle \text { Revenue }_{j, t}}{\text { Asset }_{t-1}}+\alpha_{3} \frac{\text { PPE }_{j, t}}{{\text { A } \text { Asset }_{t-1}}_{t}}+\varepsilon
$$

The discretionary accrual value is obtained after subtracting the value of the total accrual from the non-discretionary accrual value. Referring to the study (Hutton et al., 2009), an opaque financial report refers to earning management or knows as manajemen laba. To calculate the proxy for financial statement opacity in year $\mathrm{t}$, we have to adding up three consecutive years the absolute value of the annual discretionary accruals:

$$
O P A Q U E_{t-1}=\operatorname{abs}\left(\operatorname{DisAcc}_{t}\right)+\operatorname{abs}\left(\operatorname{DisAcc}_{t-1}\right)+\operatorname{abs}\left(\operatorname{DisAcc}_{t-2}\right)
$$


Dechow et al., 1(995) use annual reports for three consecutive years in year $t$ because companies with a large absolute value of discretionary accruals during the last three years are more likely to be involved in earning management, giving rise to opacity in financial statements.

\section{DATASET}

This research was conducted to determine the effect of busy directors' stock price on crash risk in Indonesia. The study was conducted using crash risk in the previous period, changes in transaction volume, returns, market-to-book value, company size, return volatility, leverage, ROA, and absolute accruals as control variables. This research uses unbalanced panel data method to overcome the issue of data availability that is different in each company.

Companies under this observation amounting to 181 companies from the year of 2014 until 2019. Following are the criteria

Table 1. 181 Companies from the year of 2014 until 2019

\begin{tabular}{lc}
\multicolumn{1}{c}{ Data } & Amount \\
\hline Companies listed on the IDX main board & 273 \\
Conducted an IPO after 2017 & $(22)$ \\
Minimum market capitalization of $20 \%$ & $(18)$ \\
The share price of IDR 50 & $(18)$ \\
Trade in under 26 weeks & $(13)$ \\
Companies with incomplete information & $(12)$ \\
Companies that have a negative market to book value consecutively & $(9)$ \\
Total Samples & $\mathbf{1 8 1}$ \\
\hline
\end{tabular}

Companies that conducted an IPO after 2017 shall be eliminated from the samples because their complete financial statement is only available from the year of 2015. Meanwhile, this research starts from 2014. Companies with share price of IDR 50 is eliminated because it is considered as the bottom price.

Table 2. Descriptive Statistic

\begin{tabular}{|c|c|c|c|c|c|}
\hline Variable & Mean & Median & Max & Min & Std. Dev. \\
\hline \multicolumn{6}{|l|}{ Dependent Variable } \\
\hline NCSKEWt & $-0,272531$ & $-0,246263$ & 2,073935 & $-3,09156$ & 0,967707 \\
\hline DUVOLt & $-0,074$ & $-0,073747$ & 0,372471 & $-0,527749$ & 0,173093 \\
\hline \multicolumn{6}{|l|}{ Independent Variable } \\
\hline BOARDSIZE $E_{t-1}$ & 5,046667 & 5 & 12 & 2 & 1,864658 \\
\hline $\begin{array}{l}\% \text { BUSYDIRECTORS } \\
\text { Moderation Variable }\end{array}$ & 0,233664 & 0,166667 & 1 & 0 & 0,235461 \\
\hline $\begin{array}{l}\text { FAMOWN }_{t-1} \\
\text { Control Variable }\end{array}$ & 0,162009 & 0 & 0,896 & 0 & 0,26037 \\
\hline$D_{T U R N}$ & $-0,001699$ & -0.000401 & 0.167443 & -0.129923 & 0.032073 \\
\hline$R E T_{t-1}$ & 0,001814 & 0,000748 & 0,045406 & $-0,01838$ & 0,010139 \\
\hline$S I G_{t-1}$ & 0,053554 & 0,049024 & 0,14758 & 0,013962 & 0,023843 \\
\hline$S I Z E_{t-1}$ & 22,52654 & 22,47707 & 26,62609 & 18,66907 & 1,628308 \\
\hline$R O A_{t-1}$ & 0,078939 & 0,06395 & 0,52024 & $-0,12085$ & 0,094675 \\
\hline$M B V_{t-1}$ & 2,887441 & 1,575 & 29,0918 & 0,13 & 4,596717 \\
\hline
\end{tabular}




\begin{tabular}{llllll}
$L E V_{t-1}$ & 0,257866 & 0,2533 & 0,80747 & 0 & 0,181164 \\
ABSACC $_{t-1}$ & 0,31499 & 0,226408 & 1,998513 & 0,037588 & 0,319187 \\
\hline
\end{tabular}

Winsorize method is performed on the dependent variable at the level of $1 \%$ for the top data and $99 \%$ for the lowest data in order to reduce the impact of outliers. The study used panel data regression analysis with the Eviews data processing program which includes 8 types of industries based on the SIC Division.

The dependent variables in this investigation are negative conditional skewness (NCSKEW) and down to up volatility (DUVOL), which are proxies for stock price crash risk. The NCSKEW variable has a mean value of -0.272531 with maximum value 2.073935 and minimum value 3.09156. The negative mean value on NCSKEW indicates that the companies in the study sample have a positively skewed return distribution. This illustrates that the companies in the sample have a low crash risk. Skewness is, as explained by Lind et al., (2018), a condition where the frequency of values in the observation is more on the left side, then the distribution has a positive slope (positively skewed). The mean value of -0.29726 indicates that the frequency of values is more on the left side. As research conducted by Bae et al., (2006), Indonesia is one of the samples in their research which is classified as a developing country, indicating that countries in this category have a positive slope. Bae et al., (2006) states that this positive value indicates that stock markets in the more developed countries are actually a better processor of economic information. In the DUVOL variable, the mean value is -0.074 with maximum value 0.372471 and minimum value 0.527749 . These results indicate that Indonesia has a fairly low volatility. Board size is the number of commissioners in a company and an average of 5 commissioners. A maximum value of 12 indicates that there are companies in the study sample that have 12 Commissioners. In the BUSYDIR variable, an average of $23 \%$ of Commissioners holds multiple positions on the company board. Then, in the sample of companies investigated, there were all Commissioners who held multiple positions. In the FAMOWN variable, which is a proxy for the ownership structure, the mean (median) value is $0.162009(0)$, which means that around $16.2 \%$ of companies listed on the IDX classified in the main board are family-owned companies. The FAMOWN variable has a maximum value of 0.896 or $89.6 \%$ which indicates that companies listed on the IDX are included in the main board with a standard deviation of $26 \%$.

The next variable is the control variable. The first is DTURN, turnover by volume. The mean value of the company's DTURN is -0.001699 with a maximum value of 0.167443 , a minimum value of -0.129923 , and a standard deviation of 0.032073 . The second variable is the company's yield with a mean value of 0.001814 , with the lowest value of -0.01838 , and the largest value of 0.045406 , and a standard deviation of 0.010139 . The third control variable is SIGMA, the standard deviation of the stock returns. From these variables, the mean value is 0.053554 with a maximum value of 0.14758 , a minimum value of 0.013962 and a standard deviation of 0.023843. The fourth control variable is SIZE, the company size calculated from the logarithm of natural market value which shows a mean value of 22.52654, a maximum value of 26.62609, a minimum value of 18.66907 and a standard deviation of 1.628308 . The fifth control variable is ROA, a ratio to measure the company's profitability. The mean value is $0.078939(7.9 \%)$ with a maximum value of $0.52024(52 \%)$, a minimum value of $-0.12085(-12 \%)$, and a standard deviation of 0.094675 . The sixth control variable is BM which is the market to book value with a mean value of 2.887441 , a maximum value of 29.0918 and a minimum value of 0.13 with a standard deviation of 
4.596717. The sixth control variable is LEV, which is the level of debt with a mean value of 0.257866 , a maximum value of 0.80747 , a minimum value of 0 and a standard deviation of 0.181164 . From the sample of companies, it can be seen that the average company has a fairly low level of leverage. The last variable, ABSACC, is an earnings management variable where the absolute value of the variable shows a mean value of 0.31499 with a maximum value of 1.998513 , a minimum value of 0.037588 and a standard deviation of 0.319187.

Table 3. Correlation Analysis

\begin{tabular}{|c|c|c|c|c|c|c|c|c|c|c|c|c|c|}
\hline & $\begin{array}{c}\text { NCSKE } \\
\text { W }\end{array}$ & DUVOL & BSIZE & $\begin{array}{c}\text { \%BUSYDI } \\
\mathrm{R}\end{array}$ & FAMOWN & DTURN & RET & SIG & SIZE & ROA & MBV & LEV & $\begin{array}{l}\text { ABSA } \\
\text { CC }\end{array}$ \\
\hline NCSKEW & 1 & & & & & & & & & & & & \\
\hline DUVOL & $-0,0297$ & 1 & & & & & & & & & & & \\
\hline BSIZE & 0,0060 & $-0,0023$ & 1 & & & & & & & & & & \\
\hline $\begin{array}{l}\text { \%BUSYDI } \\
\mathrm{R}\end{array}$ & 0,0183 & $-0,0486$ & 0,1409 & 1 & & & & & & & & & \\
\hline FAMOWN & 0,0040 & 0,0091 & $-0,1417$ & 0,0221 & 1 & & & & & & & & \\
\hline DTURN & $-0,0397$ & 0,0260 & $-0,0152$ & 0,0099 & 0,0245 & 1 & & & & & & & \\
\hline RET & $-0,3060$ & $-0,0546$ & 0,0113 & $-0,0385$ & 0,0169 & 0,0021 & 1 & & & & & & \\
\hline SIG & $-0,2780$ & 0,1017 & $-0,0392$ & $-0,0869$ & $-0,0084$ & 0,0219 & 0,3549 & 1 & & & & & \\
\hline SIZE & $-0,0218$ & $-0,1363$ & 0,3866 & 0,0382 & $-0,0540$ & 0,0216 & 0,1071 & $-0,1798$ & 1 & & & & \\
\hline $\mathrm{ROA}$ & $-0,0232$ & $-0,0013$ & $-0,0276$ & $-0,0086$ & 0,0575 & $-0,0036$ & 0,0446 & $-0,0421$ & 0,0589 & 1 & & & \\
\hline MBV & 0,0391 & $-0,0519$ & 0,0147 & $-0,0060$ & $-0,0706$ & $-0,0014$ & $-0,0097$ & $-0,0977$ & 0,2670 & 0,0396 & 1 & & \\
\hline LEV & 0,0314 & 0,0456 & $-0,0148$ & $-0,0388$ & 0,0561 & $-0,0109$ & $-0,0413$ & 0,0627 & $-0,0712$ & $-0,0390$ & $\begin{array}{r}0,053 \\
0\end{array}$ & 1 & \\
\hline ABSACC & 0,0157 & 0,0278 & $-0,0106$ & $-0,0374$ & $-0,0098$ & 0,0198 & 0,0227 & 0,0022 & 0,0169 & $-0,0382$ & $\begin{array}{r}0,052 \\
2\end{array}$ & $\begin{array}{r}0,094 \\
0\end{array}$ & 1 \\
\hline
\end{tabular}

The data were normally distributed after the Jarque Bera test was performed with a probability value of 0.296601 for NCSKEW and a probability value of 0.059062 at DUVOL. There is no multicollinearity problem because VIF is below 10. All correlation coefficients are somewhat low, which is below 0.8 , therefore the collinearity of these variables is not an issue (Gujarati \& Porter, 2009)

\section{RESULTS}

Table 4. Negative Conditional Skewness

\begin{tabular}{lcclcc}
\hline \multirow{2}{*}{$\begin{array}{c}\text { Independent } \\
\text { Variable }\end{array}$} & \multicolumn{2}{c}{ Model 1 } & $\begin{array}{c}\text { Independent } \\
\text { Variable }\end{array}$ & \multicolumn{2}{c}{ Model 2 } \\
\cline { 2 - 6 } & Coef & Std. Error & & Coef & $\begin{array}{c}\text { Std. } \\
\text { Error }\end{array}$ \\
\hline $\begin{array}{l}\text { Lagged Period 1 (t- } \\
\text { 1) Dependent }\end{array}$ & & & $\begin{array}{l}\text { Lagged Period 1 } \\
(\mathrm{t}-1) \text { Dependent }\end{array}$ & & \\
Variable & -0.138084 & 0.067962 & Variable & -0.135147 & 0.067124 \\
BSIZE(-1) & -0.044757 & 0.139480 & BSIZE(-1) & -0.064064 & 0.143588 \\
\%BUSYDIR(-1) & -0.520686 & 0.575988 & \%BUSYDIR(-1) & -0.348475 & 0.553068 \\
FAMOWN(-1) & -0.638225 & 0.785418 & FAMOWN(-1) & -0.000433 & 1.100918
\end{tabular}




\begin{tabular}{|c|c|c|c|c|c|}
\hline \multirow{2}{*}{ DTURN(-1) } & \multicolumn{5}{|c|}{ \%BUSYDIR(-1)* } \\
\hline & 0.000554 & 0.001534 & FAMOWN(-1) & -1.707353 & 1.595031 \\
\hline RET(-1) & -1.862448 & 7.186373 & DTURN(-1) & 0.000545 & 0.001542 \\
\hline SIG(-1) & $8.862660^{* * *}$ & 3.714454 & RET(-1) & -1.624560 & 7.138056 \\
\hline SIZE(-1) & -0.129080 & 0.178001 & SIG(-1) & $8.835236^{* * *}$ & 3.714183 \\
\hline $\operatorname{ROA}(-1)$ & $-2.230084^{* *}$ & 0.991663 & SIZE(-1) & -0.138476 & 0.176210 \\
\hline $\mathrm{BM}(-1)$ & $0.013143^{* *}$ & 0.006850 & $\operatorname{ROA}(-1)$ & $-2.236236^{* *}$ & 0.991004 \\
\hline $\operatorname{LEV}(-1)$ & -0.976101 & 1.154773 & $\mathrm{BM}(-1)$ & $0.012968^{* *}$ & 0.006906 \\
\hline \multirow[t]{2}{*}{$\operatorname{ABSACC}(-1)$} & -0.457548 & 0.147851 & $\operatorname{LEV}(-1)$ & -1.062718 & 1.164964 \\
\hline & & & ABSACC $(-1)$ & -0.460252 & 0.147785 \\
\hline
\end{tabular}

Test of over identifying restriction

Hansen J Test $\quad 0.277107$

0.305123

Serial correlation test of order

$\begin{array}{lll}\text { AR1 } p \text {-value } & 0.0001 & 0.0000\end{array}$

AR2 $p$-value $\quad 0.4183 \quad 0.2585$

Source: The author's processed result (2020)

Note: * significant at $10 \%$ confidence level; ** significant at the $5 \%$ confidence level; *** significant at the $1 \%$ confidence level. The table presents the results of model regression testing using the GMM method. The independent variable used in the study is board activity to test how much influence the busyness of the board has on the risk of falling stock prices. All variable definitions are in Table 1. The p-values of AR1 and AR2 are the p-values of the tests for first and second-order autocorrelation in residuals, distributed asymptotically as $\mathrm{N}$ (0.1) under the null hypothesis without serial correlation (no serial correlation). Hansen J is a redundant identification limitation test, distributed asymptotically as $X^{\wedge} 2$ under the null hypothesis of no correlation between the instrument and the error term. The probability used in this model is 1-tailed.

Table 5. Down to Up Volatility

\begin{tabular}{|c|c|c|c|c|c|}
\hline \multirow{2}{*}{$\begin{array}{l}\text { Independent } \\
\text { Variable }\end{array}$} & \multicolumn{2}{|c|}{ Model 1} & \multirow[t]{2}{*}{$\begin{array}{c}\text { Independent } \\
\text { Variable }\end{array}$} & \multicolumn{2}{|c|}{ Model 2} \\
\hline & Coef & Std. Error & & Coef & $\begin{array}{l}\text { Std. } \\
\text { Error }\end{array}$ \\
\hline Lagged Period 1 (t- & & & Lagged Period 1 & & \\
\hline 1) Dependent & & & (t-1) Dependent & & \\
\hline Variable & -0.162183 & 0.072279 & Variable & -0.170272 & 0.071381 \\
\hline BSIZE(-1) & 0.009199 & 0.021936 & BSIZE(-1) & 0.006320 & 0.022004 \\
\hline \%BUSYDIR(-1) & -0.102082 & 0.100474 & \%BUSYDIR(-1) & -0.013666 & 0.099862 \\
\hline FAMOWN(-1) & 0.009852 & 0.163842 & FAMOWN(-1) & 0.177554 & 0.176656 \\
\hline & & & \%BUSYDIR(-1)* & & \\
\hline (1) & 0.000141 & 0.000418 & FAMOWN(-1) & $-0.497136^{* *}$ & 0.216854 \\
\hline RET(-1) & -0.970905 & 1.064180 & DTURN(-1) & 0.000135 & 0.000414 \\
\hline SIG(-1) & 0.135225 & 0.711235 & $\operatorname{RET}(-1)$ & -1.029712 & 1.022349 \\
\hline $\operatorname{SIZE}(-1)$ & -0.010357 & 0.026911 & SIG(-1) & 0.233943 & 0.690302 \\
\hline ROA(-1) & $-0.019637^{* * *}$ & 0.002976 & SIZE(-1) & -0.011759 & 0.027043 \\
\hline
\end{tabular}




\begin{tabular}{llllll} 
BM(-1) & $\mathbf{0 . 0 0 1 6 9 9 * *}$ & 0.000952 & $\operatorname{ROA}(-1)$ & $\mathbf{- 0 . 0 1 9 9 1 7 ^ { * * * }}$ & 0.002962 \\
$\operatorname{LEV}(-1)$ & 0.185107 & 0.167512 & $\operatorname{BM}(-1)$ & $\mathbf{0 . 0 0 1 6 5 0 *}$ & 0.000969 \\
ABSACC(-1) & -0.057831 & 0.028613 & LEV(-1) & 0.162548 & 0.165928 \\
& & & ABSACC(-1) & -0.058302 & 0.028526 \\
\hline
\end{tabular}

Test of over identifying restriction

Hansen J Test $\quad 0.327571$

0.297632

Serial correlation test of order

$\begin{array}{lll}\text { AR1 } p \text {-value } & 0.0000 & 0.0000 \\ \text { AR2 } p \text {-value } & 0.2379 & 0.2014\end{array}$

Source: the author's processed result (2020)

Note: * significant at $10 \%$ confidence level; ${ }^{* *}$ significant at the $5 \%$ confidence level; ${ }^{* * *}$ significant at the $1 \%$ confidence level. The table presents the results of model regression testing using the GMM method. The independent variable used in the study is board activity to test how much influence the busyness of the board has on the risk of falling stock prices. All variable definitions are in Table 1. The p-values of AR1 and AR2 are the p-values of the tests for first and second-order autocorrelation in residuals, distributed asymptotically as $\mathrm{N}$ (0.1) under the null hypothesis without serial correlation (no serial correlation). Hansen J is a redundant identification limitation test, distributed asymptotically as $x^{\wedge} 2$ under the null hypothesis of no correlation between the instrument and the error term. The probability used in this model is 1-tailed.

The GMM method is used to reduce the problem of endogeneity in order to eliminate bias in research due to the dynamic relationship between busy directors which is part of the governance attributes and crash risk. This is because endogeneity leads to biased and inconsistent parameter estimates that make reliable conclusions questionable. Previous period for negative conditional skewness (NCSKEW) and down to up volatility (DUVOL) have a negative and significant relationship with future crash risk. Thus, it can be concluded that companies with high crash risk in the previous period will face a lower risk of stock price crash in the future. This is in line with research conducted by W. Li \& Cai (2016) and Jebran et al. (2020). The results show that board size (BSIZE) does not have a significant effect on the risk of future stock price crashes on both the NCSKEW and DUVOL proxies. Presentation of commissioners (BUSYDIR) who held multiple positions in research models 1 and 2, using either NCSKEW or DUVOL, did not have a significant effect on the risk of stock price crash. This result is in line with the findings of Andreou et al., (2016). The interaction between family ownership in the DUVOL model 2 study shows a negative and significant relationship. This shows that there is an alignment effect because the largest shareholders have an interest in the company. This can be explained by the alignment effect theory, which is a way to reduce agency cost in which family ownership functions as a supervisor and controls the best interests of all shareholders. Trading volume (DTURN) shows a positive and insignificant relationship. This is different from previous studies which show a positive and significant relationship. Meanwhile, research by J. Chen et al., (2001) documented a positive and significant relationship between trading volume and crash risk in both the cross section and the time series due to the difference of options. Return (RET) has a positive and significant relationship to the DUVOL proxy. This indicates that high returns in the previous period can lead to the risk of crash in stock prices in the future. Meanwhile, for DUVOL, research models 1 and 2 have a negative and insignificant relationship. The positive relationship between stock returns and the risk of stock price crash is explained in the stochastic bubble model. The standard deviation of stock returns (SIG) on NCSKEW illustrates a positive and significant relationship. This suggests that firms with volatile stock returns 
are likely to face the risk of stock price crashes in the future. Company size (SIZE) has no effect on the risk of stock price crashes. These results are in line with research conducted by Jebran et al. (2020) and Srinidhi \& Liao (2020). Return on assets (ROA) as a profitability ratio has a negative and statistically significant relationship on the two stock price crash proxies. Companies with good operational performance have a low risk of stock price crashes in the future, as explained by Hutton et al. (2009). Market-to-book value (MBV) in the NCSKEW and DUVOL proxies has a positive and significant impact on the risk of stock price crashes. Companies with a higher market price than the fundamental stock price tend to have a higher risk of stock price crashes. Companies with high market value tend to have lower crash risk in the future (Srinidhi \& Liao, 2020). The debt level ratio (LEV) does not have a significant effect on the risk of stock price crashes. Absolute accrual (ABSACC) has a negative and significant relationship with crash risk in the proxy for crash risk in stock prices. This shows that the more companies do not implement accounting conservativism, the lower the risk of future stock price crashes. These results indicate that managers have discretionary power to perform earnings management. Bae et al. (2006) made a conclusion based on the discretionary-disclosure hypothesis that managers in developing countries have greater discretion to carry out aggressive earnings management. Consequently, this managerial behavior will provide a positive slope of stock returns.

\section{CONCLUSION AND SUGGESTIONS}

\section{Conclusion}

This research was conducted to determine the effect of family ownership on the relationship of busy directors and stock price crash risk. Based on the study that has been carried out, the conclusions that can be drawn are as follows:

1. Multiple positions do not have significant effect on the risk of stock price crash in the two proxies for stock price crash. The effect of Multiple positions can be explained through two theories, namely the board busyness hypothesis which will strengthen the risk of stock price crash. Therefore, the effect of multiple positions will exacerbate the risk of a stock price crash. In the reputational hypothesis theory, the multiple position effect will lead to alignment which can reduce the risk of stock price crashes. Meanwhile, in this study there is no significant influence between multiple positions and the risk of stock price crashes. This can be explained from an econometric perspective namely cross over interaction, where positive and negative effects may cancel out (cancel out) each other so the effect does not exist. When multiple positions are interacted with family ownership, it shows a negative and significant result, it shows that the negative effect of multiple positions on the risk of stock price crash is more dominant in family firms than in non-family companies. It can be concluded that family companies when selecting Commissioners who have multiple positions tend to choose Commissioners, which certainly does not pose a risk of crash. The elected commissioners are expected to be able to encourage more transparent financial reporting and encourage management not to carry out aggressive earnings management.

2. Family companies show an alignment effect between shareholders and managers by appointing busy directors because of their reputation and expertise, which can encourage management to be more transparent in presenting company information, thereby reducing the risk of stock price crashes. 
3. Absolute accrual as management's discretion in performing earning smoothing is one of the risks inherent in this research. The results show that the more the company performs earnings management, the lower the risk of stock price crash the company faces. There is a study which states that earning smoothing is carried out by management to improve the unclear information about the future prospects of a company. Thus, it is essential to control unfamiliar traders 'perceptions of earnings volatility in order to minimize the losses expected by investors due to lack of knowledge.

\section{Suggestion} follows:

Suggestions that can be provided in accordance with the results of the study are as

1. For scholars, further research is expected to add more governance attributes to see their effect on stock price crash risk in addition to multiple positions such as board diversity, related party transactions, or ownership structures by institutional investors.

2. For regulators, studying board composition is essential because the formulation of policies for board structure has implications for the governance system. Regulators and market players in the capital market emphasize the significant role of the Commissioners as a core mechanism for corporate governance because their presence can promote economic growth and financial stability of a country. POJK No. 33/2014 only provides a maximum number of multiple positions for individuals in listed companies. This shows that individuals can still hold multiple positions beyond the limits set for non-listed companies. Thus, the provisions for multiple positions in non-listed companies also need to be reviewed to assess effectiveness in conducting supervision.

\section{ACKNOWLEDGMENT}

Authors would like to express our gratitude to the person with the greatest direct contribution, Kevin E. Sianipar FEBUI for his assistance during data collection and for making an invaluable contribution to this research.

\section{REFERENCE}

Adams, R. B., Hermalin, B. E., \& Weisbach, M. S. (2010). The role of boards of directors in corporate governance: A conceptual framework and survey. Journal of Economic Literature, 48(1), 58-107. https://doi.org/10.1257/jel.48.1.58

Ali, A., Chen, T. Y., \& Radhakrishnan, S. (2007). Corporate disclosures by family firms. Journal of Accounting and Economics, 44(1-2), 238-286. https://doi.org/10.1016/j.jacceco.2007.01.006

An, H., \& Zhang, T. (2013). Stock price synchronicity, crash risk, and institutional investors. Journal of Corporate Finance, 21(1), 1-15. https:// doi.org/10.1016/j.jcorpfin.2013.01.001

Andreou, P. C., Antoniou, C., Horton, J., \& Louca, C. (2016). Corporate Governance and Firm-specific Stock Price Crashes. European Financial Management, 22(5), 916-956. 
https://doi.org/10.1111/eufm.12084

Arellano, M., \& Bond, S. (1991). Some Tests of Specification for Panel Data: Monte Carlo Evidence and an Application to Employment Equations. The Review of Economic Studies, 58(2), 277. https:// doi.org/10.2307/2297968

Arellano, M., \& Bover, O. (1995). Another look at the instrumental variable estimation of error-components models. Journal of Econometrics, 68(1), 29-51. https://doi.org/10.1016/0304-4076(94)01642-D

Bae, K. H., Lim, C., \& John Wei, K. C. (2006). Corporate governance and conditional skewness in the world's stock markets. Journal of Business, 79(6), 2999-3028. https://doi.org/10.1086/508006

Barontini, R., \& Caprio, L. (2006). The effect of family control on firm value and performance. European Financial Management, 12(5), 689-723. https://doi.org/10.1111/J.1468-036X.2006.00273.X

Bates, D. S. (2000). Post-'87 crash fears in the S\&P 500 futures option market. Journal of Econometrics, 94(1-2), 181-238. https://doi.org/10.1016/S0304-4076(99)00021-4

Beasley, M. S. (1996). An emperical analysis of relation between directors and financial fraud. In The Accounting Review (Vol. 71, Issue 4, pp. 443-465).

Bleck, A., \& Liu, X. (2007). Market transparency and the accounting regime. Journal of Accounting Research, 45(2), 229-256. https://doi.org/10.1111/j.1475679X.2007.00231.x

Blundell, R., \& Bond, S. (2000). blundell-Bond-ER.pdf. 19(3).

Booth, J. R., \& Deli, D. N. (1996). Factors affecting the number of outside directorships held by CEOs. Journal of Financial Economics, 40(1), 81-104. https://doi.org/10.1016/0304-405X(95)00838-6

Callen, J. L., \& Fang, X. (2013). Institutional investor stability and crash risk: Monitoring versus short-termism? Journal of Banking and Finance, 37(8), 3047-3063. https://doi.org/10.1016/j.jbankfin.2013.02.018

Campbell, J. Y., \& Hentschel, L. (1992). No news is good news. An asymmetric model of changing volatility in stock returns. Journal of Financial Economics, 31(3), 281-318. https:/ / doi.org/10.1016/0304-405X(92)90037-X

Chang, X., Chen, Y., \& Zolotoy, L. (2017). Stock Liquidity and Stock Price Crash Risk. In Journal of Financial and Quantitative Analysis (Vol. 52, Issue 4). https://doi.org/10.1017/S0022109017000473

Chang, Y. C., Kao, M. S., \& Kuo, A. (2014). The influences of governance quality on equity-based entry mode choice: The strengthening role of family control. International Business Review, 23(5), 1008-1020. https://doi.org/10.1016/j.ibusrev.2014.03.003 
Chen, J., Hong, H., \& Stein, J. C. (2001). Forecasting crashes: Trading volume, past returns, and conditional skewness in stock prices. Journal of Financial Economics, 61(3), 345381. https:// doi.org/10.1016/S0304-405X(01)00066-6

Chen, X., Harford, J., \& Li, K. (2007). Monitoring: Which institutions matter? Journal of Financial Economics, 86(2), 279-305. https://doi.org/10.1016/j.jfineco.2006.09.005

Dechow, P. M., Sloan, R. G., \& Sweeney, A. P. (1995). Dechow_et_al_1995.pdf. In The accounting Review (Vol. 70, Issue 20, pp. 193-225).

Fama, E. F., \& Jensen, M. C. (1983). Agency Problems and Residual Claims. The Journal of Law and Economics, 26(2), 327-349. https://doi.org/10.1086/467038

Fich, E. M., \& Shivdasani, A. (2012). Are busy boards effective monitors? Corporate Governance: Recent Developments and New Trends, 9783642315(2), 221-258. https://doi.org/10.1007/978-3-642-31579-4_10

Field, L., Lowry, M., \& Mkrtchyan, A. (2013). Are busy boards detrimental? Journal of Financial Economics, 109(1), 63-82. https://doi.org/10.1016/j.jfineco.2013.02.004

Gallucci, C., Santulli, R., \& Calabrò, A. (2015). Does family involvement foster or hinder firm performance? The missing role of family-based branding strategies. Journal of Family Business Strategy, 6(3), 155-165. https://doi.org/10.1016/j.jfbs.2015.07.003

Gomez-mejia, L. R., Cruz, C., Berrone, P., \& Castro, J. De. (2016). The Bind that Ties: Socioemotional Wealth Preservation in Family Firms The Bind that Ties: Socioemotional Wealth Preservation in Family Firms. The Academy of Management Annals, 6520(October), 37-41. https://doi.org/10.1080/19416520.2011.593320

Habib, A., \& Hasan, M. M. (2016). Auditor-provided tax services and stock price crash risk. Accounting and Business Research, 46(1), 51-82. https://doi.org/10.1080/00014788.2015.1035222

Harvey, C. R., \& Siddique, A. (2000). American Finance Association Conditional Skewness in Asset Pricing Tests. The Journal of Finance, 55(3), 1263-1295. http://www.jstor.org/stable/222452

Harymawan, I., Nasih, M., Ratri, M. C., \& Nowland, J. (2019). CEO busyness and firm performance: evidence from Indonesia. Heliyon, 5(5), e01601. https://doi.org/10.1016/j.heliyon.2019.e01601

Hong, H., \& Stein, J. C. (2003). Differences of Opinion, Short-Sales Constraints, and Market Crashes. Review of Financial Studies, 16(2), 487-525. https://doi.org/10.1093/rfs/hhg006

Hutton, A. P., Marcus, A. J., \& Tehranian, H. (2009). Opaque financial reports, R2, and crash risk. Journal of Financial Economics, 94(1), 67-86. https://doi.org/10.1016/j.jfineco.2008.10.003

Jebran, K., Chen, S., \& Zhang, R. (2020). Board diversity and stock price crash risk. 
Research in International Business and Finance, 51, 101122. https://doi.org/10.1016/j.ribaf.2019.101122

Jin, L., \& Myers, S. C. (2006). R2 around the world: New theory and new tests. Journal of Financial Economics, 79(2), 257-292. https://doi.org/10.1016/j.jfineco.2004.11.003

Kaplan, S. N., \& Reishus, D. (1990). Outside directorships and corporate performance. Journal of Financial Economics, 27(2), 389-410. https://doi.org/10.1016/0304405X(90)90061-4

Kim, J. B., Li, L., Lu, L. Y., \& Yu, Y. (2016). Financial statement comparability and expected crash risk. Journal of Accounting and Economics, 61(2-3), 294-312. https://doi.org/10.1016/j.jacceco.2015.12.003

Kim, J. B., Li, Y., \& Zhang, L. (2011a). CFOs versus CEOs: Equity incentives and crashes. Journal of Financial Economics, 101(3), 713-730. https://doi.org/10.1016/j.jfineco.2011.03.013

Kim, J. B., Li, Y., \& Zhang, L. (2011b). Corporate tax avoidance and stock price crash risk: Firm-level analysis. Journal of Financial Economics, 100(3), 639-662. https://doi.org/10.1016/j.jfineco.2010.07.007

Kim, J. B., \& Zhang, L. (2014). Financial reporting opacity and expected crash risk: Evidence from implied volatility smirks. Contemporary Accounting Research, 31(3), 851-875. https://doi.org/10.1111/1911-3846.12048

Kim, J. B., \& Zhang, L. (2016). Accounting Conservatism and Stock Price Crash Risk: Firm-level Evidence. Contemporary Accounting Research, 33(1), 412-441. https://doi.org/10.1111/1911-3846.12112

Kim V, J.-B., \& Zhang, L. (2012). Accounting Conservatism and Stock Price Crash Risk: Firm level Evidence. Contemporary Accounting Research, Forthcoming, 412-441.

Kothari, S. P., Shu, S., \& Wysocki, P. D. (2009). Do managers withhold bad news. Journal of Accounting Research, 47(1), 241-276. https://doi.org/10.1111/j.1475679X.2008.00318.x

Li, W., \& Cai, G. (2016). Religion and stock price crash risk: Evidence from China. China Journal of Accounting Research, 9(3), 235-250. https://doi.org/10.1016/j.cjar.2016.04.003

Li, X., Wang, S. S., \& Wang, X. (2017). Trust and stock price crash risk: Evidence from China. Journal of Banking and Finance, 76(2004), 74-91. https://doi.org/10.1016/j.jbankfin.2016.12.003

Lind, D. A., Marchal, W. G., \& Wathen, S. A. (2018). Statistical Techniques in Business \&. In Economics.

Masulis, R. W., \& Mobbs, S. (2014). Independent director incentives: Where do talented directors spend their limited time and energya. Journal of Financial Economics, 111(2), 
406-429. https://doi.org/10.1016/j.jfineco.2013.10.011

Miralles-Marcelo, J. L., Miralles-Quirós, M. del M., \& Lisboa, I. (2014). The impact of family control on firm performance: Evidence from Portugal and Spain. Journal of Family Business Strategy, 5(2), 156-168. https://doi.org/10.1016/j.jfbs.2014.03.002

Oudah, M., Jabeen, F., \& Dixon, C. (2018). Determinants linked to family business sustainability in the UAE: An AHP approach. Sustainability (Switzerland), 10(1). https://doi.org/10.3390/su10010246

Pearson, A. W., Carr, J. C., \& Shaw, J. C. (2008). Toward a theory of familiness: A social capital perspective. Entrepreneurship: Theory and Practice, 32(6 SPEC. ISS.), 949-969. https://doi.org/10.1111/j.1540-6520.2008.00265.x

Pritchard, A. C., Ferris, S. P., \& Jagannathan, M. (2003). Too Busy to Mind the Business? Monitoring by Directors with Multiple Board Appointments Part of the Business Organizations Law Commons, and the Securities Law Commons. The Journal of Finance, LVIII(3), 1087-1111. http:/ / repository.law.umich.edu/articles

Srinidhi, B., \& Liao, Q. (2020). Family firms and crash risk: Alignment and entrenchment effects. Journal of Contemporary Accounting \& Economics, 100204. https://doi.org/10.1016/j.jcae.2020.100204

Taras, V., Memili, E., Wang, Z., \& Harms, H. (2018). Family involvement in publicly traded firms and firm performance: a meta-analysis. Management Research Review, 41(2), 225-251. https://doi.org/10.1108/MRR-05-2017-0150

Tilba, A., \& Mcnulty, T. (2013). Engaged versus Disengaged Ownership: The Case of Pension Funds in the UK. Corporate Governance: An International Review, 21(2), 165182. https://doi.org/10.1111/j.1467-8683.2012.00933.x

Utama*, C., \& Utama**, S. (2019). Board of Commissioners in Corporate Governance, Firm Performance, and Ownership Structure. INTERNATIONAL RESEARCH JOURNAL OF BUSINESS STUDIES, 12(2), 111-136. Retrieved from http://www.journal.prasetiyamulya.ac.id/index.php/jurnalirjbs/article/vie $\underline{w} / 1345$

Villalonga, B., Amit, R. H., Trujillo, M.-A., \& Guzmán, A. (2015). Governance of Family Firms Belén Villalonga. 1-43.

Wintoki, M. B., Linck, J. S., \& Netter, J. M. (2012). Endogeneity and the dynamics of internal corporate governance. Journal of Financial Economics, 105(3), 581-606. https://doi.org/10.1016/j.jfineco.2012.03.005

Yeung, W. H., \& Lento, C. (2018). Ownership structure, audit quality, board structure, and stock price crash risk: Evidence from China. Global Finance Journal, 37(October 2017), 1-24. https:// doi.org/10.1016/j.gfj.2018.04.002

Indonesia Capital Market Law 1995 
Indonesia Company Law 2007

Indonesia Financial Service Authority Rule POJK No. 33 Year 2014

PSAK No. 1 (Revised 2009) 